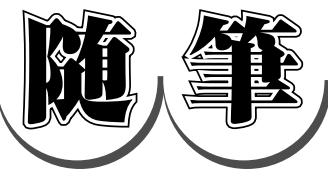

\title{
事始め, あれこれ*
}

\section{1.はじめに}

大阪大学接合科学研究所の中田一博教授から昨年 末，溶接学会誌の随筆コーナーへの執筆依頼があっ た、随筆なぞ書いたことがないなあと思いつつ，原 稿提出までには 9 か月ほども間があるとのことで, 安請け合いをしてしまった。今年も半年が過ぎそろ そろ書き始めなければ思いパソコンに向かったもの の，方向が定まっている訳ではない.

北海道立文学館が最近入手した有島武郎（18781923）と波多野秋子の間で交わされた書簡など 7 点 の資料を 7 月 1 日から一般公開している（有島の未 収録書簡 2 点，秋子の未公開書簡 2 点を含む）。有 島は小説『カインの末裔』，『或る女』，『生まれ 出づる悩み』や評論『惜しみなく愛は奪ふ』などで 知られる北海道ゆかりの作家である，有島は大正 12 年（1923） 2 月11日付の書簡で「仕事の端緒が胸の 処までは来ているのですがまだ手の処までやって来 ません」と，婦人公論の編集記者であった秋子に創 作上の悩みを訴えている。有島と秋子は同年 6 月 9 日未明，軽井沢の別荘で心中したが，北海道文学館 理事長神谷忠孝氏によると，今回見つかった書簡に よって「軽井沢心中」の通説としての秋子の自殺願 望，夫・波多野春房の金銭要求には修正が必要にな るかも知れないとのことである。ともあれ著名な文 筆家でさえ書くことの悩みを抱えていることを考え

*原稿受付 平成21年7月 17日

**正員 社団法人北見工業技術センター運営協会 Member, Kitami Industrial Technology Center
ると，随筆事始めの筆が進まないのは当然であり， 救われる思いがする.

「随筆」の意味を調べたことはこれまでになかった が，少し古びた手元の広辞苑第二版によると，「見 聞·経験·感想などを筆にまかせて何くれとなく記し た文章。枕草子，徒然草の類。漫筆。随想」とあ る、筆にまかせて何くれとなく記すにしても学会誌 の随筆には査読がないとすると，原文がそのまま読 者の目に入り，国立国会図書館かどこかには子々 孫々まで残るかも知れない。となると，徒然草や枕 草子は論外にしても随筆なるものを多少勉強しなけ ればと思い，このところ寺田寅彦全集（岩波書店） に読み耽っている。

\section{2. 随筆事始め}

寺田寅彦（1878-1935）は，『尺八の音響学的研 究』で理学博士の学位を取得し, 潮汐の副振動, X 線による結晶構造解析や金平糖の角，ひび割れなど 身近な事象を研究対象にした物理学者であり, 文系 と理系の融合を試みた随筆家，俳人（吉村冬彦の雅 号）としても知られる.

全集第 7 巻に「重兵衛さんの一家」という婦人公 論（1933年 1 月） から転載の随筆がある。4 歳の頃 の寅彦は, 寺田家の隣に住んでいた重兵衛さん一家 の子供たちと, 重兵衛さんの晚酌の膳を取り巻いて おとぎ話などに聞き入っていた。学校教育の中から は聞くことのできない「しばてん」（木の葉天狗） と相撲を取る話とか，「えんこう」（河童）を釣る 話とかである。寅彦はよほど気に入っていたのか, 雀と烏の捕まえ方の記述は具体的である. 雀の捕ま 
え方は概ね次のようである。まず庭一面に柿の葉を 並べてその上に焼酎に浸した米粒を載せておく，雀 が来てそれを食うとまもなく酔いを発していい気持 ちになり，柿の葉を布団にぐっすり寝込んでしま う。秋の日がかんかん照りつけるので柿の葉が乾燥 してじりじりと巻き上がり，いつの間にかそっくり と雀を包んで動けないように縛ってしまう。頃を見 計らって篣で掻き集めると米俵に 1 俵ぐらいは容易 に捕れるという具合である。

重兵衛さんの次男で寅彦より 1 つ 2 つ年上の亀さ んからもいろいろ教わっている。学校では割と成績 のよかった自分の作った凩はぜんぜん揚がらず，鳥 や魚捕りもまるで駄目であったのに対し，成績がび りに近かった亀さんの凩は風の弱い時にも強い時に もよく揚がり，鳥や魚の秘密をすっかり心得ている ようによく捕まえるので大いに尊敬したと述懐して いる．亀さんは田んほ道に小さな落とし穴を作って 人を踏み込ませたり，路上の牛糞の上に蛍を載せて おいて人を驚かせたりする相当のいたずらっ子で, 寅彦の母や祖母は一緒に遊ぶのをあまり喜ばなかっ たらしい。重兵衛さん一家との幼年時代の経験につ いて，冒険というものに対する本能的な興味の最初 の小さな炎が点火され，学校では教わらないいたず ら教育も今から考えると有益で貴重であったと述べ ている．寅彦はその後40年間，重兵衛さん一家とは 音信普通であったが，婦人公論に載ったこの随筆が 縁となって中国の大連で医者になっていた亀さんの 消息に接している，寅彦の随筆は，中途で休むこと なくほとんど一気に読み下せるものが多い。これは 身近な話題を扱っているだけでなくその筆力に違い ないが，「事始め，あれこれ」も一気読みに耐える よう書きたいものである.

\section{3. 溶接事始め}

その 1 寅彦の幼年時代を垣間見たのを機会に60 年ほど前をちょっと振り返ることにする。学 3 年 生までの通学路沿いには，今ではもう見掛けること のできなくなった農家相手の鍛治屋や蹄鉄屋さんが 何軒もあった。行帰りの時間帯には大抵，土間の戸 が広く開いていたので，幾人かでその前に屈み込ん で作業に見入った。ふいご（蜦）で風を送ってコー クス炬で鉄を真っ赤に焼き，金床の上で伸ばしたり 曲げたり巧みに加工していた。真っ赤な鉄同士に砂
のようのものを振り掛けてハンマーで吒くと, くっ つくのが不思議に思えた。鍛接（沸かし付け）であ り，砂状のものは硼砂である．蹄鉄屋では半月型の 大きな刃物で馬の蹄を切ったり，やすりで削ったり していた．型合わせのために焼いた蹄鉄を押し付け るとジィーという音と一緒に蹄の焦げた臭いと煙が 立ち込めたが，馬は一向に動じないのに驚いた。

「お前はどこの子だ。面白いか」などとたまには親 方から声を掛けられたかも知れないが，その当たり は定かではない。

フロントグリルに蹄鉄を飾った車を見掛けること がある．馬は人にぶつからないという縁起からのよ うであり，私の家にも 1 頭分がある（写真 1 ）。ペ ルシュロン系の重種馬が装着していた冬用で, 凍っ た道でも滑らないように高さ $23 \mathrm{~mm}$ ほどの四角錐 の爪が 1 蹄鉄当たり 2 個ずつ鍛接されている。ペル シュロンは，軽種馬のサラブレッドと違って今では 輓曳競走（通称ばんえい競馬，ばんば）でしか見る ことのできない体重 1 トン以上にもなる大型馬であ る. 温厚な性格で力が強いことから北海道では 1950 年代まで農耕用に推奨され, 戦時中には軍馬として 出征した。ばんえい競馬は重量物を積んだ鉄製の㮔 を障害物のある直線コースで曳く世界に例のない競 技で，北海道遺産に指定されている，半世紀以上も 前に鍛冶屋の親方が打ち，ペルシュロンが曳いたプ ラウ 2 台の金属部分をそのまま脚に利用したベンチ が庭にある（写真 2 ）。土がうまく返るように曲面 を工夫し，刃先に鋼を鍛接したプラウは見ようによ っては芸術的でさえある。

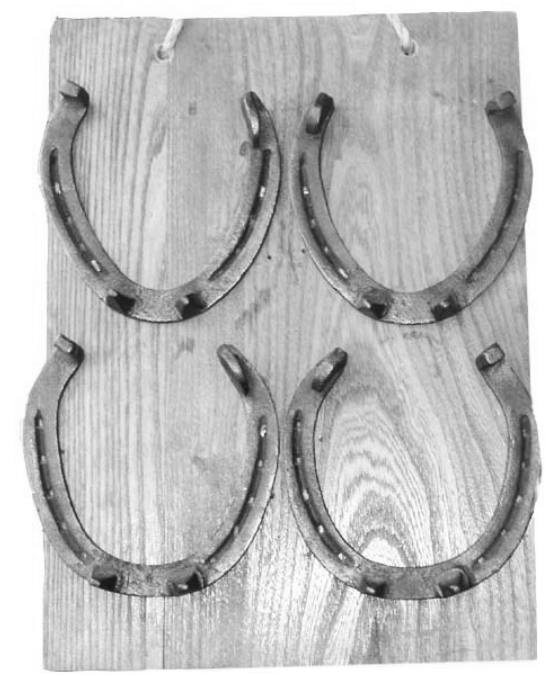

図 1 ペルシュロンに装着の冬用蹄鉄 


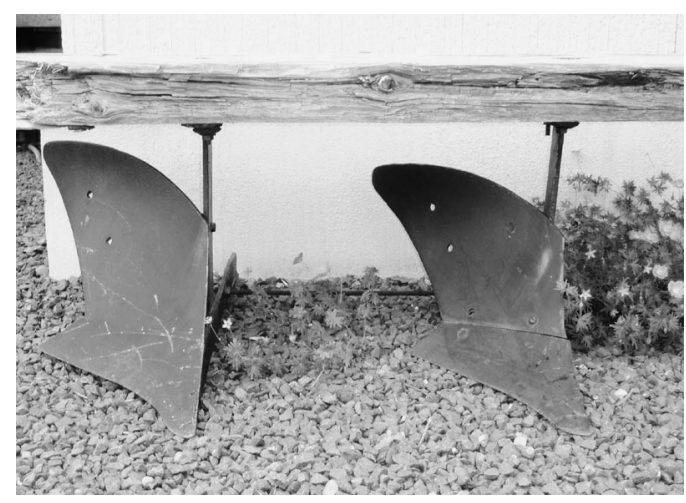

図 2 ペルシュロンの曳いたプラウ利用のベンチ

その 2 職業や専門分野, 研究テーマをどのよう に決めたか，との問いに即答できる人は多くはない と思われる，私の場合も全くそうであり，ややこじ つけの部分はあるが次のようである。 5 年間の民間 企業を経て北見工業大学機械工学科の助手に採用さ れた（1969）。企業では缶詰用の半田付け缶の製造 に係わっていたので溶接と関係があったことになる が，この当たりのことは「製罐・缶詰よもやまばな し」（軽金属溶接 Vol.40 (2002) No.9）で若干触れ ている.

配属された研究室には鋳造・溶接分野と切削加工 分野の助教授 2 人がおられ (現名誉教授)，管理し ていた実習工場の技官を加えて 7 人の所帯であっ た。短期大学から 4 年制に移行して丁度 4 年目で大 学院はなく, 学位取得者も学長を含め全学で 3 人と いう時代であったが，全体が研究に取り組み始めた 時期で教職員も学生も総じて活気があった（その 後，修士課程は1984年，博士課程は1997年設置）。 当初は 2 人の先生の研究を手伝い，学生の実験・実 習にも当たったので，鋳造や切削も多少は噛ったこ とになる。自分も研究テーマを持たなければと思い つつ暗中模索の日々であった。会員になりたての溶 接学会, 機械学会, 精機学会 (現精密工学会) の各 機関誌を今では考えられないほど丹念に読み，講演 会にも極力参加した。また助手会を仲間と立ち上げ て学長選挙への参加を要望したりした．助手の選挙 権は同年，学長選挙規程に盛り达まれたがこれは全 国的に珍しいことであった。

助手 3 年目に文部省の科学研究費補助金申請（奨 励研究 A）が採択になった。課題は $\left\lceil\mathrm{CO}_{2}\right.$ 溶接装置 ノズルの改良に関する研究」であり，導入したばか りの半自動アーク溶接に対し，「どうも風に弱いな あ」と言う溶接・鍛造の得意な鍛治屋さん出身の技
官の話がヒントであった。ともあれ溶接分野で点火 された最初の小さな炎であり，外部資金の獲得であ った. 2 人の先生は比較的自由に振舞わせてくれた ので, 次の科研費も同じ溶接分野でということにな り結局, 現在まで続いてしまった。もし切削の分野 で科研費が採択されていたとすると, プラウの鐉接 の話は, 切削か研削の話に変わっていたかも知れな い. 外部資金といえば当時の大学の研究者にとって は科研費がほとんど唯一であり, 他省庁を含めると 目移りするほどメニューの多い現在は隔世の感があ る.

その 3 研究分野が決まったからには遅ればせな がら専門的に勉強しなければと思い, 大阪大学溶接 工学研究所（現接合科学研究所）が初めて全国公募 した共同研究員に応募し, 荒田吉明教授 (現名誉教 授, 学士院会員, 文化勲章受賞者）の指導を得るこ とになった。助手 8 年目であった。応募テーマは 「溶接アーク音」であり, 溶接アーク現象を音響信 号によって解析・制御することが目標であった。こ のテーマについては，アーク溶接の際に風が当たる と音に変化を生じること，「溶接は目と耳です る」という前記技官の話がヒントであった。荒田先 生は当時, 電子ビームやレーザ加工に関する研究を 推進しておられた。溶接アーク音であれば北見に戻 ってからも継続できるという配慮から, 溶接工学科 の丸尾大教授 (現名誉教授) に身柄を預けられ14か 月間, 研究所と工学部に籍を置くことになった。溶 接アーク音については第 9 報までを溶接学会誌（論 文集を含む）と IIWで発表した。またアーク溶接 における耐風効果については第 3 報までを発表し た。初期の論文には未熟な部分が多いが, 最初の論 文が揭載された時にはその後味わうことのできない 震えにも似た感動を覚えた。この間, 米国オ八イオ 州立大学溶接工学科に招聘研究員として籍を置く機 会を得たが，これも荒田先生のご高配による。『溶 接アーク音に関する基礎的研究』と題してまとめた 論文により1982年, 大阪大学から工学博士の学位を 授与された。審査委員は荒田教授, 丸尾教授, 西口 公之教授, 井上勝敬教授, 仲田周次教授 (現名誉教 授）であった。各先生から餞の言葉をいただいた。 荒田先生からは「研究は重箱の隅をつつくか, 新た な重箱を作るかのどちらかだ」, 丸尾先生からは 「研究は言い過ぎず遠慮せず」，「一期一会」であ った。当時研究所長であった圓城敏男教授からは 


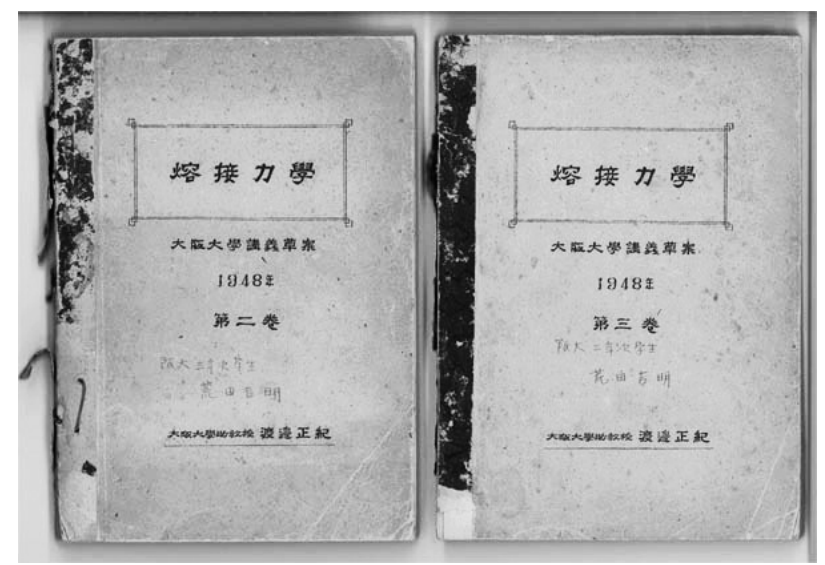

図 3 渡邊正紀著『熔接力學』第二巻，第三巻

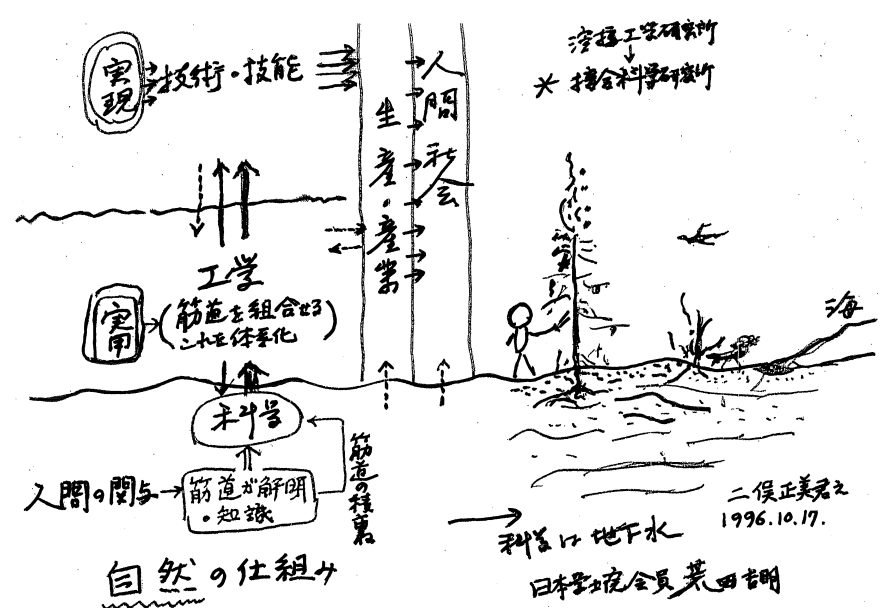

図 4 工学の位置付け（荒田吉明）

「学位は米と同じく有難いが，足の裏に付いた米粒 のようなもので食うことはできない」という趣旨の 言葉をいただいた。

書棚に渡邊正紀著『熔接力學』大阪大學講義草案第 二巻, 第三巻 (1948) がある (写真 3 ). 第二巻は 342 ページ, 第三巻は 295 ページの全て手書きのガリ版 刷りである. 表紙に「阪大三年次学生荒田吉明」の署 名があり, 所々にアンダーラインや書达みがある.荒 田先生からいただい本の中でも貴重品であるが，荒 田記念館で展示するのが適当ではないかと思ってい る. 研究所通いはその後も続くことになり，1989 年 から 2000 年までは専門委員を仰せつかった。

\section{4. 溶射事始め}

荒田・丸尾両教授から1983年頃，溶射の話を伺っ た. 丸尾先生が岡田實教授 (元大阪大学総長) とと もにプラズマ溶射の創生期を築いたことはよく知ら
れており, 先生の学位論文『プラズマジェットによ る予熱シールド溶射法の研究』も頂戴していた。材 料開発の流れは今後, バルク材から省資源化と低コ スト化に有利な溶射などコーティングへ移行すると のお話もあって, 直ちに準備に取り掛かった。プラ ズマジェット発生装置には, 厚谷郁夫教授（元北見 工業大学長）が東北大学からの赴任時に移管替えし た発光分析用のものを転用した。プラズマが最初に 噴出した時には大いに感激し， $125 \mathrm{~dB}$ 前後にも達 する音圧レベルの大きさに驚いたりもした。トーチ は小型であったので $500 \mathrm{~A}$ 対応のものを製作した が, 粉末供給装置は予算上, すぐには準備できなか った。 そこで溶射皮膜の作製は外注し，手持ちの実 験設備で可能な研究をと考え, プラズマジェットの 騒音・衝突力の測定, シールド兼用の減音装置の開 発, 耐熱性に優れた制振複合皮膜の開発, 光音響分 光法による溶射皮膜の評価などを行い溶接学会, 高 温学会で発表した。その後, 科研費や他省庁からの 
外部資金が比較的順調に入ったので順次，プラズマ 溶射，粉末式ガス溶射，ワイヤ式ガス溶射装置を導 入, 現象の解析や皮膜のキャラクタリゼーションに 必要な分析機器を設備した。また溶接を志したから にはレーザもと思い，300 W の Nd-YAGレーザ装 置を設備し（1986），プルームの構造解析を行っ た。小規模大学 (研究室) では研究設備に限界があ るが，学生にはできるだけ多くの実験機器に触れさ せたいものである。この間, 金属の微粒子・イオン を含む溶液を溶射材料に用いる「液相溶射法」，機 能粉末を内部に充填したワイヤを用いる「複合ワイ ヤ溶射法」を開発して溶接学会, 高温学会その他で 発表するとともに特許を出願した。岡田先生から岡 田記念溶接振興会「岡田奨励賞」（1992），「岡田 科学技術賞」（1997）を直接授与された時には大き な感動を覚えた。私自身は助手から講師, 助教授を 経て1989年，教授になっていた。

\section{5. 産学官連携事始め}

1960 年代は産学連携にとって冬の時代であった。 学生も教職員の一部も産学連携 (当時は産学協同と 言っていた)に否定的であった。現在も主要な外部資 金の 1 つである奨学寄付金は 1899 年 (明治 32) に制 度化されている．鉄鋼の父として著名な本多光太郎 (1870-1954) は, 住友吉左衛門の寄付金によって世界 最強の磁石鋼を完成し, 寄付者の頭文字から KS 鋼・新 $\mathrm{KS}$ 鋼と命名,「産業は研究の道場」の名言を 残している.もとより大学は, 自由な発想によって独 創的·先駆的成果を生み出し社会に還元すること, 優 れた人材を育成することを目的にしている，同時に 研究者の主体性のもとで社会から寄せられる諸問題 の解決に取り組むことも重要であり, 研究者自身の 駆動力になると考えられる.ここに1枚の $\mathrm{OHP}$ 用 原稿がある (図 4 ). 荒田先生が北見工大での特別講 演（1996）の間際に 5 分ほどで書かれたものである. 自然の仕組みの中から法則・原理を見つけて体系化 し, 技術·技能として生産·産業に結び付け, 社会に還 元するのが工学であり,「役に立つ工学」をという日 頃の㧍考えがよく表現されている.

1983年，いわゆる「民間等との共同研究」が制度 化され順次, 各大学に共同研究センターが設置され た．北見工大にセンターが設置されたのは1992年で
あり，1996年から 4 年間センター長を併任した。退 職までの約15年間, 毎年 5 件前後の共同研究に取り 組んだが, 多くは溶接·溶射に関連するもので, 相 手先は主に道内企業であった。 その背景には, 北海 道技術アドバイザーや異業種交流組織のコーディネ ーターとして1980年代の初めから係わった産業界と の交流があった。地元・本州企業を含む産学で組織 した研究会は現在も継続している。昨年秋には17年 間に渡った共同研究の成果を『溶射皮膜への水中生 物付着に関する長期観察結果』と題して発行, 増補 第 2 版を本年春に発行した。最近は複合ワイヤ溶射 法による各種機能皮膜の開発に取り組んでいる。こ れは本州大手企業の奨学寄付金（現在は委託研究） を受け1997年来続けてきた実用化研究の一環であ る。「新たな重箱」はなかなか作れそうにないが, 人生はまさに「一期一会」である.今日, 産学官 金・学学・医工・工農連携等々多様であるが, 産学 連携に当たっては相手の立場を理解し同じ土俵に立 つこと, 大学がすべきこと・すべきでないことを峻 別すべきだと思う。

\section{6.おわりに}

「事始め，あれこれ」を読んでいただけるのは， 産・学・官のいずれかに籍を置く研究者・技術者と 思われる. 研究分野やテーマの決め方は. 産の場合 には会社の方針かも知れないし, 助手 (現助教) の 場合には教授の指示かも知れない. 研究費について は産ではそれなりに十分で, 学ではいつも不足して いるかも知れない。研究費は勿論, 必要であるが, 「金がないから研究できない」は言い訳に過ぎな い.ないとはいってもまるでない訳ではないだろう から，テーマの設定によって少ない期間を乗り切れ る筈である。最も必要なのは「心の自由」ではない だろうか. 学の場合の自由度はやや大きいかも知れ ないが,「絶対自由」は存在しないだろうし, あっ たとしてもむしろ苦痛かも知れない. 寺田寅彦全集 の「学問の自由」（鉄塔，1933年 9 月の転載）の中 に, みみずの研究所に入って鯨の研究をやりたいと いった場合の話がある. 鯨の研究は許されないかも 知れない。しかし，「心の自由」はその気になれば 何時でも何処でも得られる筈であり是非, そうあり たいと思う昨今である。 